\title{
Effect of spatial scale and topography on spatial heterogeneity of soil seed banks under grazing dis- turbance in a sandy grassland of Horqin Sand Land, Northern China
}

\author{
XiaoAn ZUO ${ }^{1,2 *}$, ShaoKun WANG ${ }^{1,2}$, XueYong ZHAO ${ }^{1,2}$, WenJin $\mathrm{LI}^{3}$, Johannes KNOPS ${ }^{4}$, \\ Amy KOCHSIEK ${ }^{4}$

\footnotetext{
${ }^{1}$ Naiman Desertification Research Station, Cold and Arid Regions of Environmental and Engineering Research Institute, Chinese Academy of Sciences, Lanzhou 730000, China;

${ }^{2}$ Laboratory of Plant Stress Ecophysiology and Biotechnology, CAREERI, Chinese Academy of Sciences, Lanzhou 730000 , China;

${ }^{3}$ Key Laboratory of Arid and Grassland Ecology of Ministry of Education, Lanzhou University, Lanzhou 730000, China;

${ }^{4}$ School of Biological Sciences, University of Nebraska-Lincoln, Lincoln 62588, USA
}

\begin{abstract}
Soil seed banks play an important role in the distribution and composition of plant communities in semiarid grassland ecosystems. However, information on how spatial scale influences the spatial heterogeneity of soil seed banks in a grassland under grazing disturbance is still lacking. Based on field sampling and greenhouse germination, we measured the species composition and seed density of soil seed banks at different spatial scales $(30 \mathrm{~m} \times 30 \mathrm{~m}, 30 \mathrm{~m} \times 60 \mathrm{~m}$ and $30 \mathrm{~m} \times 90 \mathrm{~m}$ ) along a topographical gradient in a sandy grassland in Horqin Sand Land, Northern China. By applying geostatistical methods, we examined how spatial scale and topography affected the spatial distribution of soil seed banks in the study area. Our results showed that the total number of species in soil seed banks, as well as the number of dominant annuals, increased with the increase of spatial scales. Seed density in soil seed banks decreased with the increase of spatial scales due to an increase in the slopes and relative heights of the sampling points. Geostatistical analysis showed that the relative structural variance $\left(C /\left(C_{0}+C\right)\right)$ of seed density and species richness were over $65 \%$ for all spatial scales, indicating that these variables had an obvious spatial autocorrelation and the spatial structured variance accounted for the largest proportion of the total sample variance. Spatial autocorrelation of seed density in soil seed banks increased with the increase of measured scales, while that of species richness showed a reverse trend. These results suggest that the total number of species in soil seed banks is spatial scale dependent and lower topography may accommodate more seeds. Spatial distribution of seed density in soil seed banks is also scale dependent due to topographic variation. Grassland management, therefore, needs to consider local grazing disturbance regime, spatial scale and topography.
\end{abstract}

Keywords: sandy grassland; grazing disturbance; topographic variation; seed density; species richness; scale dependence; Inner Mongolia

Spatial heterogeneity is considered as an important characteristic of natural ecosystems (Palmer, 2003). Soil seed banks are defined as the total number or density of available seeds stored in the soil, representing a potential seedling emergence pattern of an area in the future (Wang et al., 2005). Spatial heterogeneity in seed availability is thought to be a major factor determining the spatial pattern of plant populations and communities (Aguiar and Sala, 1997; Nathan and Muller-Landau, 2000; Li, 2008). Studies have shown

Received 2011-11-02; accepted 2012-02-27

*Corresponding author: XiaoAn ZUO (E-mail: zuoxa@1zb.ac.cn; xazuo@126.com) 
that the formation and dynamics of soil seed banks are strongly influenced by land use history (Wellstein et al., 2007; Dölle and Schmidt, 2009) and topography (Bengtson et al., 2006; Li et al., 2009).

Many researchers have suggested that the composition and structure of soil seed banks can be greatly affected by grazing disturbance (Witkowski and Garner, 2000; Adler et al., 2001; Wang et al., 2002; Olofsson et al., 2008; Ma et al., 2010). Grazing livestock increases the dominance of annual species in the vegetation, which also results in the dominance of annuals in soil seed banks (Woldu and Mohammed Saleem, 2000). In addition, ecosystem studies are often influenced by the spatial scale at which research is conducted, especially in semi-natural grasslands where management greatly influences the vegetation and soil (Kahmen et al., 2005; Auestad et al., 2008). It has been demonstrated that the impact of grazing on species richness, herbaceous cover and biomass was more responsive at the fine scale than at the coarse scale (Landsberg et al., 2002; Oba et al., 2003).

In addition to grazing, topography may also be a key factor influencing the spatial pattern of soil seed banks (Caballero et al., 2003; Bengtson et al., 2006; Li et al., 2009). Topography may be relatively homogeneous on a large spatial scale, but can be heterogeneous at a small scale as a result of microtopographic differences (Zuo et al., 2008). Topography may also strongly influence wind dispersal of plant seeds (Yan et al., 2005), and shrub location, which is often associated with specific positions in the landscape, can enhance spatial patterns in seed dispersal (Li et al., 2008).

In arid and semiarid ecosystems, spatial scales greatly affect species diversity (Harrison et al., 2006), productivity (Oline and Grant, 2001), species-area relationships (Turner and Tjorve, 2005) and productivity-diversity relationships (Ryberg and Chase, 2004). Many studies have emphasized that species richness is obviously scale-dependent in grassland ecosystems (Crawley and Harral, 2001; Pausas et al., 2003), and the ecological significance of spatial heterogeneity of soil seed banks is very important in maintaining species coexistence and biodiversity (Ben-Natan et al., 2004; Li et al., 2009). Understanding how the spatial pattern and distribution of soil seed banks vary with spatial scale is essential for vegetation restoration and land management in semiarid grassland ecosystems.

Horqin grassland is strongly influenced by longterm fuelwood gathering, heavy grazing and reclamation, and has become one of the most severely desertified regions in northern China. In recent years, many studies on vegetation and soil seed banks have been carried out in this desertified region (Yan et al., 2005; Liu et al., 2007; Li, 2008; Ma et al., 2008; Li et al., 2009). However, there is limited information on how spatial scale and topographic features affect the spatial distribution of soil seed banks in sandy grasslands under grazing disturbance.

In this paper, we examined whether species richness in soil seed banks is still scale-dependent in a sandy grassland under grazing disturbance. We tested two hypotheses: (1) the spatial dependence of seed density in soil seed banks increases with the increase of measured scales; and (2) soil seed banks is larger at lower than at higher topographic locations.

\section{Materials and methods}

\subsection{Study area}

This study was performed in the Horqin Sand Land, which is located in the semi-arid area of Southeast Inner Mongolia, China. The study area, about $2 \mathrm{~km}$ north from the Naiman Desertification Research Station, is situated in the south-western part $\left(42^{\circ} 55^{\prime} \mathrm{N}\right.$, $120^{\circ} 42^{\prime} \mathrm{E} ; 360 \mathrm{~m}$ asl) of Horqin Sand Land. The area features a temperate, semi-arid continental and monsoonal climate, with an annual average precipitation of $360 \mathrm{~mm}, 75 \%$ received in the growing season from June to September. The annual mean open-pan evaporation is about $1,935 \mathrm{~mm}$. The annual mean temperature is around $6.4^{\circ} \mathrm{C}$, with a minimum monthly mean temperature of $-13.1^{\circ} \mathrm{C}$ in January and a maximum of $23.7^{\circ} \mathrm{C}$ in July. The annual mean wind velocity is in the range of $3.2-4.1 \mathrm{~m} / \mathrm{s}$, and the prevailing wind direction is northwestern in winter and spring (Yan et al., 2005; Zuo et al., 2009).

The soils are highly prone to wind erosion and identified as sandy chestnut soils, which are equivalent to the Orthi-Sandic Entisols of sand origin in terms of the FAO-UNESCO system (Su et al., 2006). The sandy grassland in this study is dominated by native species, 
including grasses (e.g. Cleistogenes squarrosa, Setaria viridis, Phragmites australis, Digitaria ciliaris and Leymus chinensis), forbs (e.g. Mellissitus ruthenicus, Salsola collina, Agriophyllum squrrosum and Artemisia scoparia), shrubs (e.g. Caragana microphylla, and Lespedeza davurica) and subshrubs (e.g. Artemisia halodendron and Artemisia frigida).

\subsection{Experimental design}

This research was carried out from March to September, 2009. A typical sandy grassland under long-term grazing disturbance, about $10 \mathrm{hm}^{2}$ in size, was selected for the study. A $30 \mathrm{~m} \times 90 \mathrm{~m}$ plot was established along a gentle topography, in which three spatial scales of $30 \mathrm{~m} \times 30 \mathrm{~m}, 30 \mathrm{~m} \times 60 \mathrm{~m}$ and $30 \mathrm{~m} \times 90 \mathrm{~m}$ were partitioned. Then four $90-\mathrm{m}$ long sampling transects were spaced $10 \mathrm{~m}$ apart, oriented southeast to northwest along prevailing wind direction. Along each of the four transects, sampling points were established at 1.5-m intervals, giving a total of 84, 164 and 244 sampling points in three different spatial scales, respectively. We used a hand clinometer to measure the slope of each sampling point in the $30 \mathrm{~m} \times 90 \mathrm{~m}$ plot, and the relative height at the center of each sampling point along each transect was calculated by trigonometric functions.

\subsection{Soil seed banks}

At each sampling point, a soil sample of $20 \mathrm{~m} \times 20 \mathrm{~cm}$ and $5 \mathrm{~cm}$ deep was collected before seed germination at the end of March in 2009. We used greenhouse germination to determine the composition and size of seeds in plastic trays (Li, 2008; Li et al., 2009). Plastic trays of $40 \mathrm{~cm}$ (length) $\times 30 \mathrm{~cm}$ (width) $\times 10 \mathrm{~cm}$ (height) were first filled with seed-free fine sand of about $2 \mathrm{~cm}$ thick, and then the samples were spread to form a uniform, thin layer (3-5 mm) and covered with 1-2 mm thick seed-free fine sand. The trays were placed in a greenhouse and the seed banks of each species were estimated based on the counts of seedlings that emerged over a 16-week period (after which no new seedlings emerged). During germination, the trays were watered regularly each day. Emergent seedlings were checked twice a week and then removed after species identification (Li et al., 2009).

\subsection{Data analysis}

All seed germination data were converted to seed den- sity per square meter. To determine the effect of sampling size and spatial scale on soil seed banks, species-area curve in the $30 \mathrm{~m} \times 90 \mathrm{~m}$ plot was also established by calculation $(1,15,30,60,90,150,300,600$, $900,1,800$ and $2,700 \mathrm{~m}^{2}$ ).

The data distribution was tested for normality with the Kolmogorov-Smirnov test at the 0.05 significance level. For species richness and seed density not passing the normal distribution test, we transformed the data (e.g. log-transformation and square root transformation) before analysis. The spatial variability of soil seed banks at different scales was analyzed using geostatistical technique (Isaaks and Srivastava, 1989; Zuo et al., 2008, 2009; Wang et al., 2010). The spatial autocorrelation analysis provides a quantitative estimate of the spatial correlation between two samples as a function of their separation distance (Isaaks and Srivastava, 1989). The spatial analysis integrated semivariance as follows:

$$
\gamma(h)=\frac{1}{2 N(h)} \sum_{i=1}^{N(h)}\left[z\left(x_{i}\right)-z\left(x_{i}+h\right)\right]^{2} .
$$

Where, $N(h)$ is the number of sample pairs at each distance interval $h$; and $z\left(x_{i}\right)$ and $z\left(x_{i}+h\right)$ are the values of variables at any two places separated by a distance $h$. The experimental variogram is calculated for several lag distances. The lag $h$ is defined as a vector with both distance and direction. In practice, the direction effect is considered by computing experimental variograms according to different directions of the $h$ vector. The spatial structure of the data is determined by fitting a mathematical model to the experimental semivariogram. A spherical or exponential model was fitted to the observed variables, which showed that these variables had spatial autocorrelations within the sampling scales that we used. The model was fitted by means of a least square method (Cannavacciuolo et al., 1998; Zuo et al., 2008, 2009).

The parameters of the modeled variogram include information on: (a) spatial autocorrelation range or A, the separation distance at which spatial dependence is apparent; (b) nugget value or $\mathrm{C}_{0}$, the level of random variation within the data; (c) structural component or $\mathrm{C}$, the level of structure variation within the data; and (d) sill or $\left(\mathrm{C}_{0}+\mathrm{C}\right)$, the total variation present. An especially important parameter, relative structural variance, 
was calculated as $\mathrm{C} /\left(\mathrm{C}_{0}+\mathrm{C}\right)$. RSS or residual sums of squares provided an exact measure on how well the model fits the variogram data, with lower RSS indicating better model fits. GS+ (Version 9.0, Gamma Design Software) uses RSS to choose parameters for each of the variogram models by determining the combination of parameter values that minimizes RSS for any given model (Gamma Design Software, 2000).

Differences among the different spatial scales were compared using a multiple comparison and one-way analysis of variance (ANOVA) procedures, coupling a Tukey's post-hoc comparison $(P<0.01)$. The descriptive statistical parameters and the significance test were calculated using SPSS (version 16.0).

\section{Results and discussion}

\subsection{Changes in compositions of soil seed banks}

The seedlings observed throughout this experiment represented 27 species in a $30 \mathrm{~m} \times 90 \mathrm{~m}$ plot, and total number of species increased with the increase of spatial scales (Table 1, Fig. 1), suggesting that species number in soil seed banks is scale dependent in the grazing grassland, being consistent with findings from other studies (Crawley and Harral, 2001; Pausas et al., 2003; He et al., 2006).

In the study area, annual plants comprised $76 \%$ of all local species and related to $99 \%$ of the total seed count, and the seed density of the annuals, Artemisia

Table 1 Seed density changes of dominant seedlings germinating from soil seed banks under grazing disturbance at different spatial scales in the study area

\begin{tabular}{|c|c|c|c|c|c|}
\hline \multirow{3}{*}{ Species } & \multirow{3}{*}{$\mathrm{LF}$} & \multicolumn{3}{|c|}{ Plot scale } & \multirow{3}{*}{$P$} \\
\hline & & $30 \mathrm{~m} \times 30 \mathrm{~m}$ & $30 \mathrm{~m} \times 60 \mathrm{~m}$ & $30 \mathrm{~m} \times 90 \mathrm{~m}$ & \\
\hline & & \multicolumn{3}{|c|}{$\left(\right.$ seeds $\left./ \mathrm{m}^{2}\right)$} & \\
\hline Melissitus ruthenicus (L.) C. W. Chang & PL & $0.31 \pm 2.80^{\mathrm{a}}$ & $0.31 \pm 2.79^{\mathrm{a}}$ & $0.31 \pm 2.76^{\mathrm{a}}$ & 1.000 \\
\hline Cleistogenes squarrosa (Trin.) Keng & PG & $3.44 \pm 12.42^{\mathrm{a}}$ & $5.94 \pm 13.87^{\mathrm{a}}$ & $4.20 \pm 11.80^{\mathrm{a}}$ & 0.259 \\
\hline Artemisia halodendron Turcz. ex Bess. & PS & $0^{\mathrm{a}}$ & $0^{\mathrm{a}}$ & $1.13 \pm 6.52^{\mathrm{a}}$ & 0.029 \\
\hline Lespedeza davurica (Laxam.) Schindl. & $\begin{array}{l}\text { PS, } \\
\text { PL }\end{array}$ & $0.63 \pm 3.93^{\mathrm{a}}$ & $2.97 \pm 29.85^{\mathrm{a}}$ & $2.15 \pm 24.28^{\mathrm{a}}$ & 0.782 \\
\hline Corispermum macrocarpum Bunge. & $\mathrm{AF}$ & $135.00 \pm 395.42^{\mathrm{a}}$ & $285.00 \pm 550.24^{\mathrm{ab}}$ & $321.21 \pm 606.45^{\mathrm{b}}$ & 0.035 \\
\hline Euphorbia humifusa Willd. & $\mathrm{AF}$ & $1.25 \pm 6.77^{\mathrm{a}}$ & $5.78 \pm 16.64^{\mathrm{b}}$ & $7.17 \pm 18.28^{\mathrm{b}}$ & 0.020 \\
\hline Setaria viridis (L.) Beauv. & AG & $327.81 \pm 430.91^{\mathrm{a}}$ & $362.34 \pm 395.30^{\mathrm{ab}}$ & $441.91 \pm 473.40^{\mathrm{b}}$ & 0.066 \\
\hline Chloris virgata Swartz & AG & $58.13 \pm 191.38^{\mathrm{a}}$ & $71.56 \pm 194.97^{\mathrm{a}}$ & $47.03 \pm 161.33^{\mathrm{a}}$ & 0.400 \\
\hline Ceratoides latens (Losinsk.) Tsien et C.G.Ma & PS & $1.25 \pm 7.86^{\mathrm{a}}$ & $0.63 \pm 5.57^{\mathrm{a}}$ & $0.51 \pm 4.78^{\mathrm{a}}$ & 0.594 \\
\hline Eragrostis pilosa (L.) Beauv. & AG & $687.81 \pm 646.47^{\mathrm{a}}$ & $645.28 \pm 616.31^{\mathrm{a}}$ & $452.78 \pm 568.67^{\mathrm{b}}$ & 0.001 \\
\hline Artemisia scoparia Waldst. et Kit. & $\mathrm{AF}$ & $7,312.19 \pm 7,007.02^{\mathrm{a}}$ & $4,500.63 \pm 5,913.84^{\mathrm{b}}$ & $2,985.19 \pm 5,217.05^{\mathrm{c}}$ & 0.000 \\
\hline Tribulus terrestris L. & $\mathrm{AF}$ & $47.19 \pm 166.92^{\mathrm{a}}$ & $74.22 \pm 179.72^{\mathrm{a}}$ & $63.32 \pm 158.77^{\mathrm{a}}$ & 0.495 \\
\hline Chenopodium acuminatum $\mathrm{L}$. & $\mathrm{AF}$ & $2,674.06 \pm 2,429.50^{\mathrm{a}}$ & $2,349.53 \pm 2,031.85^{\mathrm{a}}$ & $2,292.93 \pm 2,167.23^{\mathrm{a}}$ & 0.389 \\
\hline Digitaria ciliaris (Retz.) Koel. Descr. Gram. & $\mathrm{AG}$ & $18.75 \pm 39.48^{\mathrm{a}}$ & $28.13 \pm 104.98^{\mathrm{a}}$ & $103.59 \pm 285.51^{\mathrm{b}}$ & 0.000 \\
\hline Aristida adscensionis L. & $\mathrm{AG}$ & $1.88 \pm 6.63^{\mathrm{a}}$ & $2.03 \pm 7.40^{\mathrm{a}}$ & $2.05 \pm 7.58^{\mathrm{a}}$ & 0.983 \\
\hline Allium mongolicum Rgl. & $\mathrm{PF}$ & $3.44 \pm 8.66^{\mathrm{a}}$ & $1.88 \pm 6.61^{\mathrm{a}}$ & $2.66 \pm 9.24^{\mathrm{a}}$ & 0.371 \\
\hline Echinops gmelini turcz. & $\mathrm{AF}$ & $1.25 \pm 5.48^{\mathrm{a}}$ & $2.19 \pm 10.26^{\mathrm{a}}$ & $1.95 \pm 9.00^{\mathrm{a}}$ & 0.745 \\
\hline Cuscuta chinensis Lam. & $\mathrm{AF}$ & $0.94 \pm 4.78^{\mathrm{a}}$ & $1.09 \pm 6.48^{\mathrm{a}}$ & $1.02 \pm 5.91^{\mathrm{a}}$ & 0.981 \\
\hline $\begin{array}{l}\text { Bassia dasyphylla (Fisch. et. Mey.) O. Kunt- } \\
\text { zae, Revis. Gen. }\end{array}$ & $\mathrm{AF}$ & $11.88 \pm 30.81^{\mathrm{a}}$ & $12.81 \pm 35.58^{\mathrm{a}}$ & $26.13 \pm 92.69^{\mathrm{a}}$ & 0.102 \\
\hline Ixeris chinensis (Thunb.) Nakai & $\mathrm{AF}$ & $1.25 \pm 6.77^{\mathrm{a}}$ & $0.94 \pm 5.53^{\mathrm{a}}$ & $2.36 \pm 10.50^{\mathrm{a}}$ & 0.233 \\
\hline Salsola collina Pall. & $\mathrm{AF}$ & $53.44 \pm 97.33^{\mathrm{a}}$ & $80.47 \pm 190.20^{\mathrm{a}}$ & $148.67 \pm 324.35^{\mathrm{b}}$ & 0.004 \\
\hline Lappula myosotis V. Wolf & $\mathrm{AF}$ & $0^{\mathrm{a}}$ & $0.31 \pm 2.80^{\mathrm{a}}$ & $10.82 \pm 54.35^{\mathrm{b}}$ & 0.048 \\
\hline
\end{tabular}

Note: Different letters indicate significant differences at $a=0.01$ level. LF, life-form; AF, annual forbs; AG, annual grass; PF, perennial forbs; PG, perennial grass; PL, perennial legume; PS, perennial shrub; values are Mean \pm SD. 


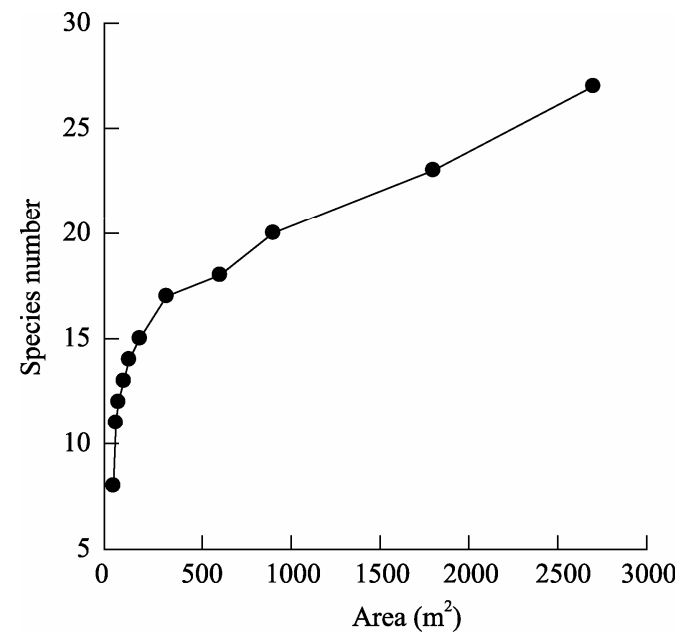

Fig. 1 Species-area curve at $30 \mathrm{~m} \times 90 \mathrm{~m}$ spatial scale in the study area

scoparia, Chenopodium acuminatum and Eragrostis pilosa, gradually decreased with the increase of measured scales. The most abundant perennial plants were Cleistogenes squarrosa and Allium mongolicum, the number of which fluctuated slightly with the increase of measured scales. The species richness of annuals increased with the increase of measured scales, while that of perennials and shrubs did not change (Table 2).

Our study suggests that at all spatial scales in a grazing grassland, annual plants dominate soil seed banks in both species richness and seed density, supporting the finding from other studies that livestock grazing favors the dominance of annual plants in vegetation and soil seed banks (Witkowski and Garner, 2000; Woldu and Mohammed Saleem, 2000; Adler et al., 2001; Wang et al., 2002; Olofsson et al., 2008; Ma et al., 2010). This may be explained by that selective grazing on dominant species reduced their vigor and presence, thus favoring the spread of less competitive but more tolerant annual species with high seed production (Noy-Meir et al., 1989; Sternberg et al., 2000; Zhao et al., 2005).

\subsection{Spatial pattern and heterogeneity of soil seed banks}

The mean seed density was significantly different among the three different spatial scales $(P<0.01)$, while mean species richness had no obvious difference (Table 3). In addition, the average values of seed density in soil seed banks decreased with the increase of measured scales. At all spatial scales, the relative structural variance, $\mathrm{C} /\left(\mathrm{C}_{0}+\mathrm{C}\right)$ of seed density and species richness in all subdivided plots were over $65 \%$, indicating that these variables had obvious spatial autocorrelation. These results showed that the spatial structured variance accounted for the largest proportion of the total sample variance. The spatial autocorrelation ranges of seed density increased with the increase of measured scales (Table 3, Fig. 2). However, the spatial autocorrelation ranges of species richness displayed no obvious changes with the increase of measured scales, indicating that the spatial autocorrelation of species richness is not scale dependent in the grazing grassland.

Figure 3 based on simple Kriging shows the spatial distribution pattern for seed density and species richness in soil seed banks at $30 \mathrm{~m} \times 90 \mathrm{~m}$ scale. As indicated, the high spatial dependence of seed density distribution was also observed in the semi-variance analysis results (Table 3 ). Kriging maps expressed that the spatial distribution of seed density showed a descending trend from southeast to northwest in the gazing grassland. In addition, the spatial distribution map of species richness showed higher degrees of spatial variability and patch fragmentation than that of seed density.

Table 2 Changes in life-form composition from soil seed banks at different spatial scales in the study area

\begin{tabular}{|c|c|c|c|c|}
\hline Life-form & Index & $30 \mathrm{~m} \times 30 \mathrm{~m}$ & $30 \mathrm{~m} \times 60 \mathrm{~m}$ & $30 \mathrm{~m} \times 90 \mathrm{~m}$ \\
\hline \multirow[t]{3}{*}{ Annual species } & Species richness & 16.00 & 22.00 & 24.00 \\
\hline & Percentage of species richness $(\%)$ & 76.19 & 78.57 & 80.00 \\
\hline & Percentage of seed density $(\%)$ & 99.92 & 99.86 & 99.84 \\
\hline \multirow[t]{3}{*}{ Perennial species } & Species richness & 3.00 & 3.00 & 3.00 \\
\hline & Percentage of species richness (\%) & 14.29 & 10.71 & 10.00 \\
\hline & Percentage of seed density $(\%)$ & 0.06 & 0.10 & 0.10 \\
\hline \multirow[t]{3}{*}{ Shrub } & Species richness & 2.00 & 3.00 & 3.00 \\
\hline & Percentage of species richness (\%) & 9.52 & 10.71 & 10.00 \\
\hline & Percentage of seed density $(\%)$ & 0.02 & 0.04 & 0.05 \\
\hline
\end{tabular}


Table 3 Descriptive statistical indices, semi-variogram model and parameters for seed density and richness at different spatial scales in the study area

\begin{tabular}{ccccccccc}
\hline Index & Scale & Model & Mean $\pm \mathrm{SD}$ & $\mathrm{C}_{0}$ & $\mathrm{C}_{0}+\mathrm{C}$ & $\mathrm{C} /\left(\mathrm{C}_{0}+\mathrm{C}\right)$ & $\mathrm{A}(\mathrm{m})$ & $\mathrm{RSS}$ \\
\hline \multirow{3}{*}{ Seed density } & $30 \mathrm{~m} \times 30 \mathrm{~m}$ & Spherical & $11,081.25 \pm 6,671.05^{\mathrm{a}}$ & 0.10 & 0.03 & 0.69 & 8.49 & 0.000 \\
& $30 \mathrm{~m} \times 60 \mathrm{~m}$ & Spherical & $8,263.42 \pm 5,922.93^{\mathrm{b}}$ & 0.01 & 0.03 & 0.69 & 43.00 & 0.001 \\
& $30 \mathrm{~m} \times 90 \mathrm{~m}$ & Spherical & $6,905.43 \pm 5,459.01^{\mathrm{c}}$ & 0.01 & 0.03 & 0.81 & 74.00 & 0.002 \\
\multirow{2}{*}{ Species richness } & $30 \mathrm{~m} \times 30 \mathrm{~m}$ & Spherical & $6.82 \pm 1.54^{\mathrm{a}}$ & 0.09 & 2.35 & 0.96 & 2.42 & 1.020 \\
& $30 \mathrm{~m} \times 60 \mathrm{~m}$ & Spherical & $7.17 \pm 1.85^{\mathrm{b}}$ & 0.06 & 3.29 & 0.98 & 2.50 & 7.740 \\
& $30 \mathrm{~m} \times 90 \mathrm{~m}$ & Exponential & $7.37 \pm 1.86^{\mathrm{b}}$ & 0.43 & 3.46 & 0.88 & 3.30 & 4.380 \\
\hline
\end{tabular}

Note: Different letters indicate significant differences at $a=0.01$ level.
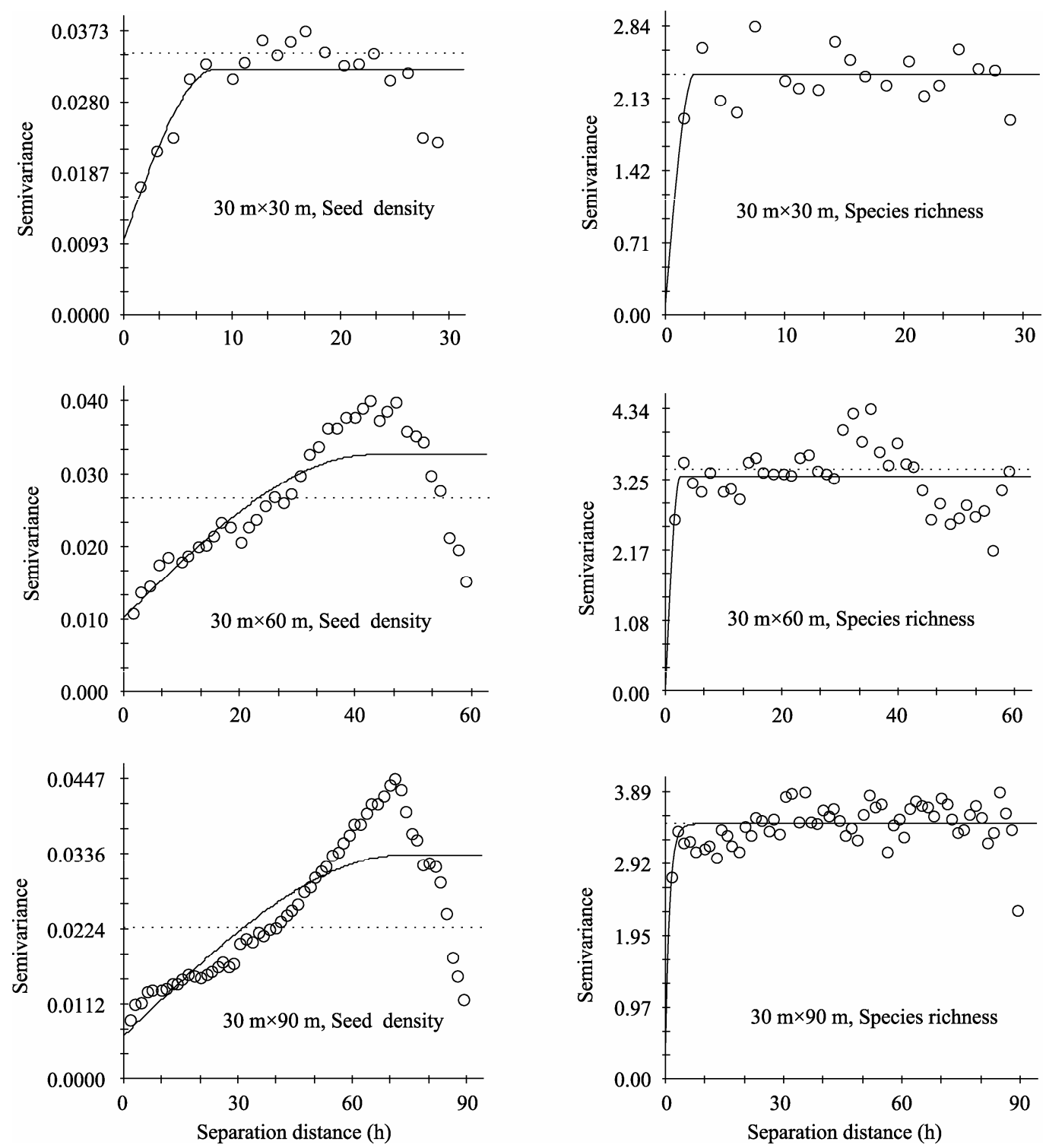

Fig. 2 Sample semivariograms for seed density and species richness at different spatial scales in the study area 

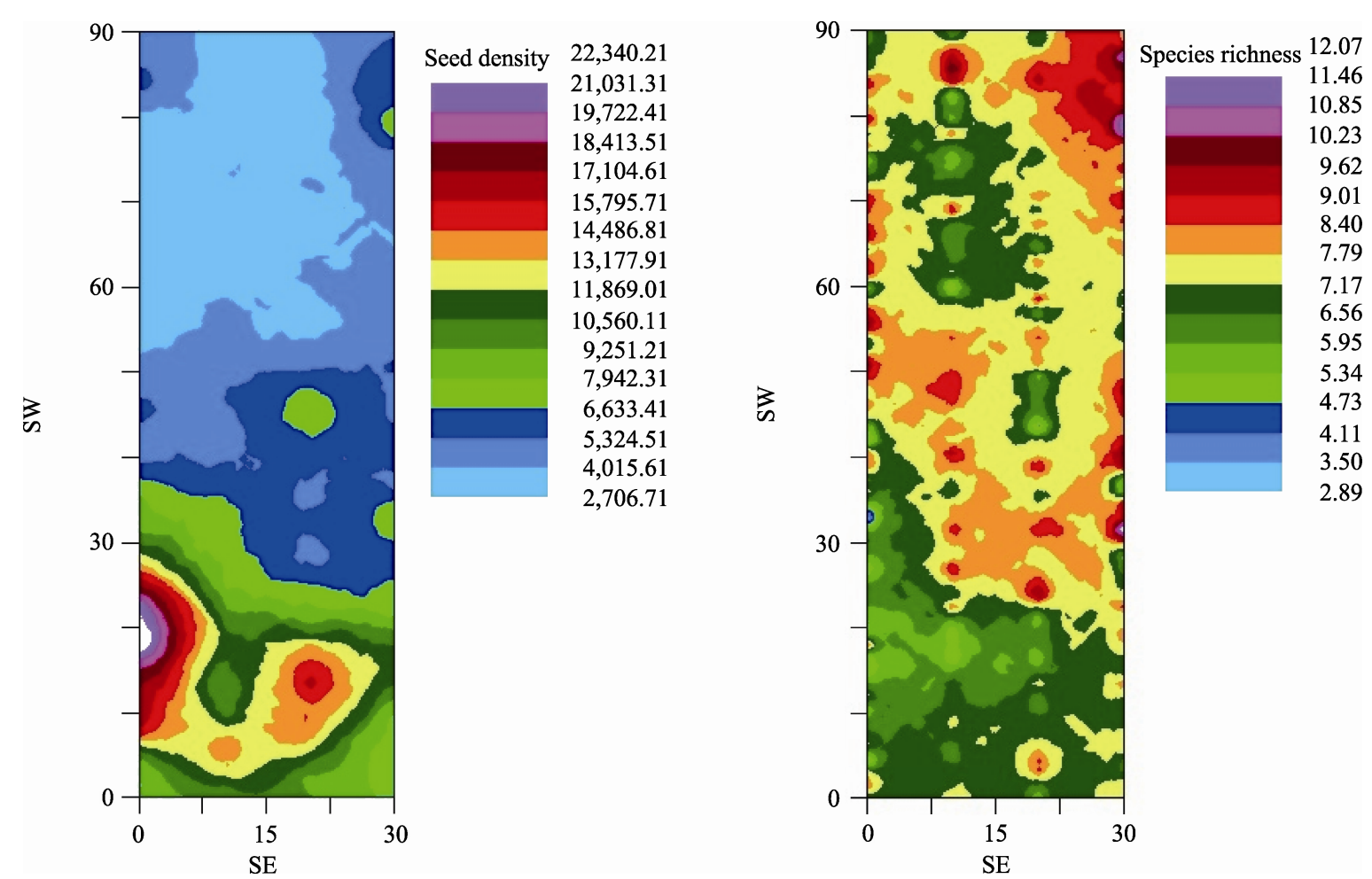

Fig. 3 Spatial distribution of seed density and species richness at $30 \mathrm{~m} \times 90 \mathrm{~m}$ spatial scale in the study area

In the grazing grassland ecosystem, the average values of soil density in soil seed banks ranged from 6,905 seeds $/ \mathrm{m}^{2}$ to 11,081 seeds $/ \mathrm{m}^{2}$, which suggests that soil seed banks are in the low and middle ranges of seed densities as compared to previously studies from other arid and semi-arid ecosystems (Caballero et al., 2005). Also, our results suggest that spatial scale has important effects on the distribution and pattern of soil seed density in this grazing grassland. But our results did not confirm that spatial autocorrelation of species richness in soil seed banks is scale-dependent (Crawley and Harral, 2001; Pausas et al., 2003). The study from Milchunas et al. (1988) suggested that species richness in grassland ecosystems may be influenced more strongly by grazing disturbance. These results further suggest that the interaction between spatial scale and grazing disturbance result in different patterns of seed density and species richness in soil seed banks in sandy grasslands.

\subsection{Effect of topography on spatial distribution of soil seed banks}

Correlation analysis showed that there was a significant negative correlation between seed density, slope and the relative heights of the sampling points in the
$30 \mathrm{~m} \times 90 \mathrm{~m}$ plot $(P<0.01)$ (Fig. 4), indicating that seed density decreased with the increase in the slope and relative height of the sampling points in the grazing grassland. These results suggest that lower topography may foster more soil seed banks in the grazing grassland.

Several previous researches have revealed that scale-dependent relationships rest on many biological, biophysical and environmental variables ( $\mathrm{Xu}$ et al., 2004). In grassland ecosystems, abiotic influences such as topographic variation and grazing disturbance drive the spatial patterns of plant communities through changes in soil moisture, wind exposure, nutrient availability and dominant species differences (Frank et al., 1994; Augustine, 2003; Li et al., 2008). Our study showed a decrease in seed density with the increase in measured scales, supporting the finding that microhabitat shaped by topography not only affects significant changes in the number of seeds, but also exerts a control over the compositions of local seed banks (Russell and Schupp, 1998; Caballero et al., 2003). This diversity in microhabitats can also be explained by small-scale variation degrees in topography and the effects of grazing that increase the number of 

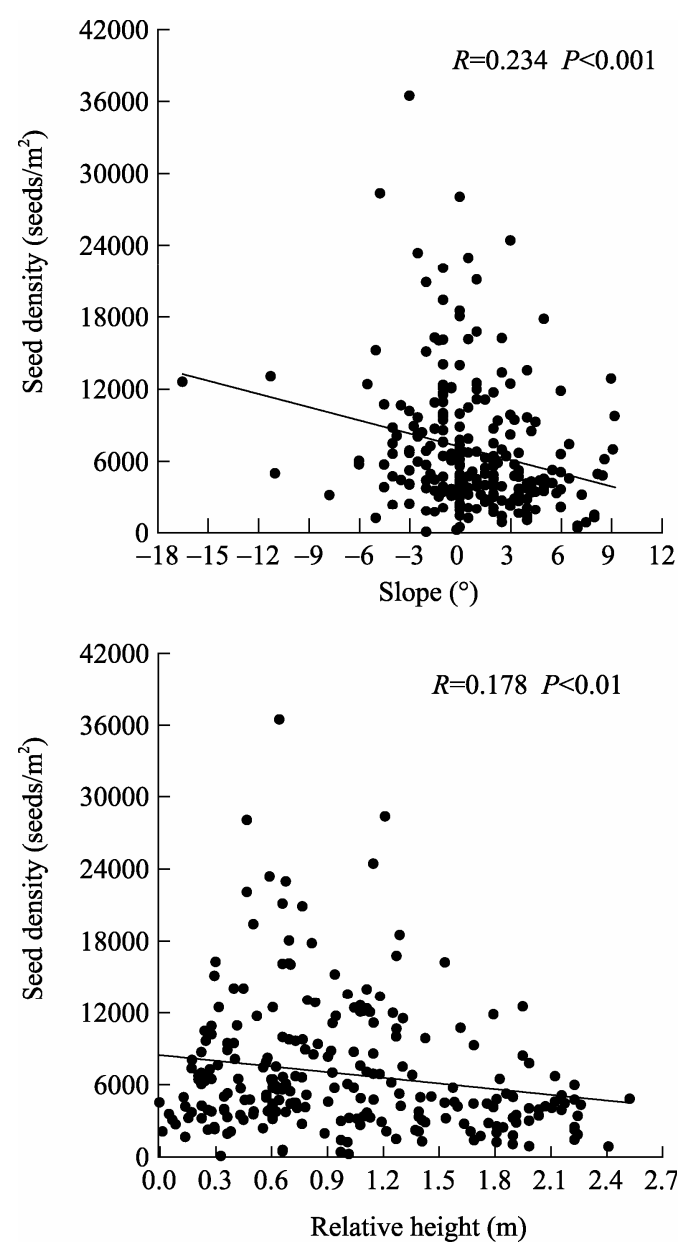

Fig. 4 Relationships between seed density in soil seed banks, slopes and relative heights of sampling points in the study area $(n=244)$

micro-patches through spatially heterogeneous defoliation, trampling, wallowing and faecal deposition (Wallis DeVries et al., 1998; Spiegelberger et al., 2006). Our study also showed that smaller topographic variations make for higher seed density in seed banks, supporting the opinion that features have an important

\section{References}

Adler P B, Raff D A, Lauenroth W K. 2000. The effect of grazing on the spatial heterogeneity of vegetation. Oecologia, 128(4): 465-479.

Aguiar M R, Sala O E. 1997. Seed distribution constrains the dynamics of the Patagonian steppe. Ecology, 78(1): 93-100.

Auestad I, Rydgren K, Økland R H. 2008. Scale-dependence of vegetation-environment relationships in semi-natural grasslands. Journal of Vegetation Science, 19(1): 139-148.

Augustine D J. 2003. Spatial heterogeneity in the herbaceous layer of a semi-arid savanna ecosystem. Plant Ecology, 167(2): 319-332. role in shaping the spatial pattern of seed dispersal and deposition in grasslands (Yan et al., 2005; Li, 2008; Li et al., 2009).

\section{Conclusions}

Our study provides an insight into the mechanisms of how spatial scale and topographic features affect the spatial pattern and heterogeneity of soil seed banks in a grazing grassland in Horqin Sand Land. Total species number in soil seed banks is scale-dependent. The same is true with the spatial autocorrelation of seed density, due to the effect of a gentle increase in topographic height. Thus, the interpretation of the spatial variation in soil seed banks of grazing grassland requires a consideration of spatial scales at which important environmental variables and disturbing factors may actually vary. This study also offers an important implication that as seed banks are concentrated in the topsoil, grassland restoration should avoid long-term grazing disturbance because annual plants favored by livestock are still to be germinated.

\section{Acknowledgements}

This paper was funded by the National Natural Science Foundation of China (41171414), the Knowledge Innovation Program of Chinese Academy of Sciences (KZCX2-EW-QN313), the National Science and Technology Support Program (2011BAC07B02), the National Basic Research Program of China (2009CB421303) and the West Light Foundation of the Chinese Academy of Sciences (0928711001). The authors thank all the members of Naiman Desertification Research Station, China Academy of Sciences, for their help in field work. Two anonymous reviewers are also thanked for their helpful comments on the manuscript.

Bengtson P, Falkengren-Grerup U, Bengtsson G. 2006. Spatial distributions of plants and gross $\mathrm{N}$ transformation rates in a forest soil. Journal of Ecology, 94(4): 754-764.

Ben-Natan G, Abramsky Z, Kotler B P, et al. 2004. Seed redistribution in sand dunes: a basis for coexistence of two rodent species. Oikos, 105(2): 325-335.

Caballero I, Olano J M, Loidi J, et al. 2003. Seed bank structure along a semi-arid gypsum gradient in Central Spain. Journal of Arid Environments, 55(2): 287-299. 
Cannavacciuolo M, Bellido A, Cluzeau D, et al. 1998. A geostatistical approach to the study of earthworm distribution in grassland. Applied Soil Ecology, 9(1-3): 345-349.

Crawley M J, Harral J E. 2001. Scale dependence in plant biodiversity. Science, 291(5505): 864-867.

Dölle M, Schmidt W. 2009. The relationship between soil seed bank, above-ground vegetation and disturbance intensity on old-field successional permanent plots. Applied Vegetation Science, 12(4): 415-428.

Frank D A, Inouye R, Huntly N, et al. 1994. The biogeochemistry of a north-temperate grassland with native ungulates: nitrogen dynamics in Yellowstone National Park. Biogeochemistry, 26(3): 163-188.

Gamma Design Software GS+5.3. 2002. Geostatistics for the Environmental Sciences. Plainwell, Michigan, USA. [2011-10-23]. http://www.gammadesign.com.

Harrison S, Davies K F, Safford H D, et al. 2006. Beta diversity and the scale-dependence of the productivity-diversity relationship: a test in the Californian serpentine flora. Journal of Ecology, 94(1): $110-117$.

He Z B, Zhao W Z. 2006. Characterizing the spatial structures of riparian plant communities in the lower reaches of the Heihe River in China using geostatistical Techniques. Ecological Research, 21(4): 551-559.

Isaaks E, Srivastava R. 1989. Applied Geostatistics. New York: Oxford University Press.

Kahmen A, Perner J, Audorff V, et al. 2005. Effects of plant diversity, community composition and environmental parameters on productivity in montane European grasslands. Oecologia, 142(4): 606-615.

Landsberg J, James C D, Maconochie J, et al. 2002. Scale-related effects of grazing on native plant communities in an arid rangeland region of South Australia. Journal of Applied Ecology, 39(3): $427-444$.

Li F R. 2008. Presence of shrubs influences the spatial pattern of soil seed banks in desert herbaceous vegetation. Journal of Vegetation Science, 19(4): 537-548.

Li F R, Zhao L Y, Zhang H, Li J L, et al. 2009. Habitat degradation, topography and rainfall variability interact to determine seed distribution and recruitment in a sand dune grassland. Journal of Vegetation Science, 20(5): 847-859.

Liu Z, Yan Q, Li X, et al. 2007. Seed mass and shape, germination and plant abundance in a desertified grassland in northeastern Inner Mongolia, China. Journal of Arid Environments, 69(2): 198-211.

Ma J L, Liu Z M. 2008. Spatiotemporal pattern of seed bank in the annual psammophyte Agriophyllum squarrosum Moq. (Chenopodiaceae) on the active sand dunes of northeastern Inner Mongolia, China. Plant and Soil, 311(1-2): 97-107.

Ma M J, Zhou X H, Du G Z. 2010. Role of soil seed bank along a dis- turbance gradient in an alpine meadow on the Tibet plateau. Flora, 205(2): 128-134.

Milchunas D G, Sala O E, Lauenroth W K. 1988. A generalized model of the effects of grazing by large herbivores on grassland community structure. American Naturalist, 132(1): 87-106.

Nathan R, Muller-Landau H C. 2000. Spatial patterns of seed dispersal, their determinants and consequences for recruitment. Trends in Ecology and Evolution, 15(7): 278-285.

Noy-Meir I, Gutman M, Kaplan Y. 1989. Responses of Mediterranean grassland plants to grazing and protection. Journal of Ecology, 77(1): 290-310.

Oba G, Weladji R B, Lusigi W J, et al. 2003. Scale-dependent effects of grazing on rangeland degradation in northern Kenya a test of equilibrium and non-equilibrium hypotheses. Land Degradation and Development, 14(1): 83-94.

Oline D K, Grant M C. 2001. Scaling patterns of biomass and soil properties: an empirical analysis. Landscape Ecology, 17(1): 13-26.

Olofsson J, de Mazancourt C, Crawley M J. 2008. Spatial heterogeneity and plant species richness at different spatial scales under rabbit grazing. Oecologia, 156(4): 825-834.

Palmer T M. 2003. Spatial habitat heterogeneity influences competition and coexistence in an African acacia ant guild. Ecology, 84(11): 2843-2855

Russell S K, Schupp E W. 1998. Effects of microhabitat patchiness on patterns of seed dispersal and seed predation of Cercocarpus ledifolius (Rosaceae). Oikos, 81(3): 434-443.

Ryberg W A, Chase J M. 2004. Connectivity, scale-dependence, and the productivity-diversity relationship. Ecology Letters, 7(8): 676-683.

Wang S K, Zhao X Y, Qu H, et al. 2010. Variation in soil water content to rainfall under Caragana microphylla shrub in Horqin Sandy Land. Journal of Arid Land, 2(3): 174-179.

Spiegelberger T, Matthies D, Müller-Schärer H, et al. 2006. Scale-dependent effects of land use on plant species richness of mountain grassland in the European Alps. Ecography, 29(4): 541-548.

Sternberg M, Gutman M, Perevolotsky A, et al. 2000. Vegetation response to grazing management in a Mediterranean herbaceous community: a functional group approach. Journal of Applied Ecology, 37(2): 224-237.

Turner W R, Tjorve E. 2005. Scale-dependence in species-area relationships. Ecography, 28(6): 721-730.

Wallis De Vries M F, Bakker J P, van Wieren S F. 1998. Grazing and Conservation Management. Dordrecht: Kluwer Academic Publishers.

Wang S M, Zhang Y, Li L, et al. 2005. Spatial distribution patterns of the soil seed bank of Stipagrostis pennata (Trin.) de Winter in the Gurbantonggut Desert of north-west China. Journal of Arid Envi- 
ronments, 63(1): 203-222.

Wang Y S, Shiyomi M, Tsuiki M, et al. 2002. Spatial heterogeneity of vegetation under different grazing intensities in the Northwest Heilongjiang Steppe of China. Agriculture Ecosystem and Environment, 90(3): 217-229.

Wellstein C, Otte A, Waldhardt R. 2007. Seed bank diversity in mesic grasslands in relation to vegetation type, management and site conditions. Journal of Vegetation Science, 18(2): 153-162.

Witkowski E T F, Garner R D. 2000. Spatial distribution of soil seed banks of three African savana woody species at two contrasting sites. Plant Ecology, 149(1): 91-106.

Woldu Z, Mohammed Saleem M A. 2000. Grazing induced biodiversity in the highland ecozone of East Africa. Agriculture Ecosystem and Environment, 79(1): 43-52.

Xu M, Qi Y, Chen J Q, et al. 2004. Scale-dependent relationships between landscape structure and microclimate. Plant Ecology, 173(1): 39-57.

Yan Q, Liu Z, Zhu J, et al. 2005. Structure, pattern and mechanisms of formation of seed banks in sand dune systems in northeastern Inner Mongolia, China. Plant and Soil, 277(1-2): 175-184.

Zhao H L, Zhao X Y, Zhang T H, et al. 2005. Desertification processes of sandy rangeland due to over-grazing in semi-arid area, Inner Mongolia, China. Journal of Arid Environments, 62(2): 309-319.

Zuo X A, Zhao H L, Zhao X Y, et al. 2008. Spatial pattern and heterogeneity of soil properties in sand dunes under grazing and restoration in Horqin Sandy Land, Northern China. Soil and Tillage Research, 99(2): 202-212.

Zuo X A, Zhao X Y, Zhao H L, et al. 2009. Spatial heterogeneity of soil properties and vegetation-soil relationships following vegetation restoration of mobile dunes in Horqin Sandy Land, Northern China. Plant and Soil, 318(1-2): 153-167. 